\title{
PERAN TEORI DALAM STUDI KOMUNIKASI
}

\author{
Heriyadi \\ Mahasiswa Pasca UIN Mataram \\ e-mail: heriyadiispring@gmail.com
}

\begin{abstract}
Communication-based on theory is very important, role theory helps get understanding and organize experiences. In theory, there are positions that play an important role in extracting information so that interpretations, judgments, and statements can be carried out easily. In addition, to reveal one's assumptions and characteristics, symbols and others cannot rely on a single perception, but must give rise to categories in a particular field that are determined by diverse space, time and types of scientific communication, including the theory of political communication, theory of interpersonal communication, intrapersonal communication theory, cultural communication theory, mass communication theory, and other theories of communication. The union between theory and communication must be in detail because in communication it is never separated from symptoms, phenomena, interactions and others that require interpretation. Thus the presence of theory in the realm of communication studies provides new colours and broader knowledge of the science of communication itself.
\end{abstract}

\section{Key Words:}

Role, Implementation, Theory, Communication 


\begin{abstract}
Abstrak
Komunikasi berlandaskan teori sangat penting, teori berperan membantu mendapatkan pengertian dan mengorganisasikan pengalaman. Di dalam teori terdapat posisi yang berperan penting dalam mengihtisarkan informasi sehingga penafsiran, penilaian, dan pernyataan dapat terlaksana dengan mudah. Selain itu, untuk mengungkap asumsi-asumsi dan karekteristik seseorang, simbol dan lainnya tidak bisa mengandalkan satu persepsi saja, melainkan harus menimbulkan katagori-katagori dalam bidang tertentu yang ditentukan ruang, waktu dan jenis keilmuan-keilmuan komunikasi yang beragam, diantaranya adalah teori komunikasi politik, teori komunikasi interpersonal, teori komunikasi intrapersonal, teori komunikasi budaya, teori komunikasi massa, dan teori komunikasi-komunikasi lainnya. Penyatuan antara teori dan komunikasi haruslah secara terperinci, karena dalam komunikasi tidak pernah terlepas dari gejala-gejala, fenomena-fenomena, intraksi dan lainnya yang membutuhkan penafsiran. Dengan demikian hadirnya teori dalam ranah studi komunikasi memberikan warna baru dan keilmuan yang lebih luas terhadap ilmu komunikasi itu sendiri.
\end{abstract}

\title{
Kata Kunci:
}

Peran, Implementasi, Teori, Komunikasi 


\section{A. Pendahuluan}

Dewasa ini komunikasi adalah suatu ilmu perilaku atau ilmu sosial dan pengetahuan budaya terapan. Disiplin ini berbagi dengan psikologi, sosiologi, antropologi, dan ilmu politik dalam mengejar pengetahuan tentang individu manusia dan kegiatan sosial. Bidang komunikasi juga berdekatan dengan bidang humaniora dan profesi. Jadi dari daya tarik lain komunikasi adalah kesempatan untuk belajar sebuah disiplin yang menggabungkan bermacam tradisi ilmu sosial, humaniora dan profesional. Jadi mengapa harus belajar komunikasi? Penjelasannya adalah; Jika anda tertarik pada ilmu sosial, seni, atau profesi, kalau minat anda adalah memhami secara lebih baik diri sendiri, hubungan, kelompok, organisasi, budaya, atau hubungan internasional, bila pusat perhatian anda adalah ilmu terapan atau kajian teoritis, komunikasi adalh bidang yang sangat penting dan berguna untuk dipelajari. ${ }^{76}$

Para pakar selama ini lebih fasih membahas "Bagaimana berkomunikasi" dari pada "Mengapa kita berkomunikasi". Dari perspektif agama, bahwa tuhanlah yang mengajari kita berkomunikasi, dengan menggunakan akal dan kemampuan berbahasa yang dianugrahkannya. Al-Quran mengatakan, "Tuhan yang Maha Pemurah, yang telah mengajarkan al-Quran. Dia menciptakan manusia, yang mengajarinya pandai berbicara". (Ar-Rahman: 1-4). ${ }^{77}$

\footnotetext{
${ }^{76}$ Brent D. Ruben, Komunikasi dan Perilaku Manusia (Jakarta: Kharisma Putra Utama, 2013), 10.

77 Deddy Mulyana, Ilmu Komunikasi Suatu Pengantar (Bandung: PT Remaja Rosdakarya, 2013), 3.
} 
Komunikasi pada dasarnya dapat terjadi dalam berbagai konteks kehidupan. Peristiwa komunikasi dapat berlangsung tidak saja dalam kehidupan manusia, tetapi juga dalam kehidupan binatang, tumbuh-tumbuhan, dan makhluk hidup lainnya. ${ }^{78}$ Jika dilihat dari segi arti bahwa komunikasi adalah proses penyampaian suatu pesan oleh seseorang kepada orang lain untuk memberitahu atau untuk mengubah sikap, pendapat, atau perilaku, baik langsung secara lisan, maupun tak langsung melalui media. $^{79}$

Komunikasi memiliki peran yang sangat vital${ }^{80}$ bagi kehidupan manusia, karena itu harus memberikan perhatian yang saksama terhadap komunikasi, khusunya teori komunikasi. Teori adalah gagasan atau ide bagaimana sesuatu dapat terjadi. Setiap orang pada dasarnya menggunakan teori untuk memandu orang memahami berbagai hal dan memberikan keputusan mengenai tindakan apa yang harus dilakukan. Teori selalu berubah dari waktu ke waktu, perubahan terjadi ketika orang menemukan hal baru atau mendapatkan perspektif baru. Teori membantu kita memutuskan apa yang penting dan apa yang tidak dan apa yang tidak penting. ${ }^{81}$

Pemahaman di atas merujuk kepada aktivitas manusia sehari-hari dalam merespon kalimat, benda, tulisan, gambar, vidio dan lainnya. Manusia dengan akal budinya bisa berkembang menjadi kemampuan berbahasa dan berkomunikasi,

78 Rochajat Harun, Elvinaro Ardianto, Komunikasi Pembangunan Perubuhan Sosial: Perspektif Dominan Kaji Ulang, dan Teori (Jakarta: Kharisma Putra Utama, 2012), 18.

79 Onong Uchiana Effendy, Dinamika Komunikasi (Bandung: PT Remaja Rosdakarya, 2004), 5.

80 Kamus Ilmiah Populer, Vital artinya sangat penting dan utama bagi hidup, bisa juga berarti penting sekali, sangat penting (untuk hajat hidup, kehidupan, dan sebagainya), 472.

81 Morissan, Teori Komunikasi Individu Hingga Massa (Jakarta: PT Fajar Interpratama Mandiri, 2015), 1-2. 
sehingga manusia disebut homo loquens dan animal symbolicum. Dengan akal budinya, manusia dapat berpikir abstrak dan konseptual sehingga disebut sebagai homo sapiens (mahkluk pemikir), yang menurut Aristoteles, Manusia adalah animal that reasons yang ditandai dengan sifat ingin tahu (all man by nature desire to know). ${ }^{82}$

Dalam hal dunia ilmu pengetahuan, teori memegang peranan penting. Oleh karena itu, penulis mencoba menggali lebih dalam tentang berbagai hal yang bekaitan tentang peran teori dalam studi komunikasi.

\section{B. Makna Teori dalam Studi Komunikasi}

William Wiersma menyatakan bahwa: A theory is a generalization or series of generalization by wich we attempt to explain some phenomena in a systematic manner. Teori adalah generalisasi atau kumpulan generalisasi yang dapat digunakan untuk menjelaskan berbagai fenomena secara sistematik. Cooper and Schindler mengungkapkan teori adalah seprangkat konsep, defenisi dan proposisi yang tersusun secara sistematis sehingga dapat digunakan untuk menjelaskan dan meramalkan fenomena. Sedangkan Haditono menjelaskan bahwa teori akan memperoleh arti yang penting, bila ia lebih banyak dapat melukiskan, menerangkan, dan meramalkan gejala yang ada. ${ }^{83}$

Makna komunikasi secara fenomena, kumpulan generalisasi, seperangkat konsep yang tersusun untuk melukiskan, menerangkan dan meramalkan merupakan

\footnotetext{
82 Aang Ridwan, Filsafat Komunikasi (Bandung: CV Pustaka Setia, 2013), 11.

${ }^{83}$ Sugiyono, Metode Penelitian Kuantitatif Kualitatif dan R\&D (Bandung: Alfabeta, 2013), 52-53.
} 
aktivitas atau prilaku yang pasti dialami oleh mamanusia yang menimbulkan pesanpesan terahadap manusia itu sendiri. Jika dilihat dari arti komunikasi bahwa setiap orang berusaha memahami setiap peristiwa yang dialaminya. Orang memberikan makna terhadap apa yang terjadi di dalam dirinya sendiri atau lingkungan sekitarnya. $^{84}$

Dalam kamus besar bahasa Indonesia (KBBI) bahwa; 1) Teori adalah pendapat yang dikemukakan sebagai keterangan mengenai suatu peristiwa kejadian, 2) Teori adalah asas dan hukum umum yang menjadi dasar atau kesenian atau ilmu pengetahuan, 3) teori adalah pendapat yang diungkapkan sebagai keterangan mengenai suatu peristiwa (kejadian). Selain itu Mc Laughlin mendefinisikan teori sebagai cara penafsiran terhadap kerampatan (generalisasi), cara peniliannya, dan pernyataannya: kerampatan itu adalah yang dihasilkan melalui penelitian. ${ }^{85}$

Teori dan komunikasi saling mengisi antara satu dengan lainnya. Luasnya komunikasi yang terjadi di cyberspace (jagat raya) mengundang banyaknya teoriteori untuk menelaah kejadian tersebut. Komunikasi dalam konteks apapun adalah bentuk dasar beradaptasi terhadap lingkungan. Menurut Rene Spitz, komunikasi adalah jembatan antara bagian luar dan bagian dalam kepribadian. Thomas M. Scheidel mengemukakan bahwa kita berkomunikasi terutama untuk menyatakan dan mendukung identitas diri, untuk membangun kontak sosial dengan orang di sekitar

\footnotetext{
${ }^{84}$ Morissan, Teori Komunikasi Individu Hingga Massa, 2.

85 Hari Wahyono, Jurnal tentang Makna dan Fungsi Teori dalam Proses Berpikir Ilmiah dan dalam Proses Penelitian Bahasa (Magelang: FKIP Universitas Magelang, 2005), 205.
} 
kita, dan untuk mempengaruhi orang lain untuk merasa berpikir, atau berperilaku seperti yang kita inginkan. ${ }^{86}$

Secara umum istilah teori dalam ilmu sosial mengandung beberapa pengertian sebagai berikut:

a. Teori adalah abstraksi dari realitas

b. Teori terdiri dari kesimpulan prinsip-prinsip dan defenisi-defenisi yang secara konseptual mengorganisasikan aspek-aspek dunia emperis secara sistematis.

c. Teori teridiri dari asumsi-asumsi, proposisi-proposisi, dan aksioma-aksioma dasar yang saling berkaitan.

d. Teori teridiri dari teorema-teorema, yakni generalisasi-generalisasi yang diterima/terbukti secara emperis.

Littlejhon dan Foss (2008) menyatakan bahwa teori pada dasarnya memiliki 4 (empat) pengertian. 1) teori adalah abstrakasi ${ }^{87}$, 2) teori merupakan susunan atau himpunan, 3) teori adalah interpretasi tentang suatu hal, dan 4) teori juga berisikan rekomendasi tentang suatu tindakan. Dari pengertian-pengertian diatas dapat disimpulkan bahwa teori pada dasarnya merupakan "Konseptualisasi atau penjelasan logis dan faktual tentang suatu fenomena. ${ }^{88}$

Pada dasarnya teori adalah panduan untuk memahami. Teori juga membantu kita untuk menggambarkan, menjelaskan, meramalkan, dan kadang-kadang

${ }^{86}$ Deddy Mulyana, Ilmu Komunikasi Suatu Pengantar, 4-17.

87 Kamus Ilmiah Populer Abstraksi; Proses pemisahan, peringkasan, penyimpulan, metode berpikir mengacu pada instruksi suatu problem dan tidak berpacu pada realita.

${ }^{88}$ Sasa Djuarsa Sendjaja, Memahami Teori Komunikasi: Pendekatan, Pengertian, Kerangka Analisis dan Perspektif (Univeritas Tebruka: Modul Kegiatan Pembelajaran, 2014), 11. 
mengendalikan fenomena dan keadaan yang kita hadapi. ${ }^{89}$ Jika dilihat dari segi bahasa istilah komunikasi berasal dari bahasa latin communication dan perkataan ini bersumber dari kata communis. Perkataan communis tersebut artinya adalah sama, dalam arti kata sama makna, yaitu semua makna mengenai suatu hal. ${ }^{90}$ Dengan demikian komunikasi menyarankan bahwa suatu pikiran, makna, atau suatu pesan dianut secara sama. ${ }^{91}$

Menurut Leksikografer (ahli kamus bahasa), komunikasi adalah upaya yang bertujuan berbagi untuk mencapai kebersamaan. Selain itu komunikasi adalah proses pertukaran informasi di antara individu melalui sistem lambang, tanda, tingkah laku (New Collegiate Dictionary edisi tahun 1997). Selain itu Everett M. Rogers mengemukakan komunikasi adalah proses pengallihan suatu ide dari sumber kepada suatu penerima atau lebih dengan maksud mengubah tingkah laku mereka. ${ }^{92}$

Berangkat dari beberapa pengertian di atas, penulis menyimpulkan bahwa teori komunikasi adalah kesimpulan fenomena-fenomena yang didapatkan, panduan untuk memahami atau membantu untuk menjelaskan, menggambarkan, meramalkan dan mengendalikan sebuah pesan-pesan baik dari lisan, tulisan, simbol, gambar, vidio dan lainnya yang bersifat emperis, abstrak aagar dapat lebih mudah difahami oleh orang lain.

\footnotetext{
${ }^{89}$ Brent D. Ruben, Komunikasi dan Perilaku Manusia, 11.

${ }^{90}$ Onong Uchiana Effendy, Dinamika Komunikasi, 3-4.

${ }^{91}$ Aang, Ridwan, Filsafat Komunikasi, 91.

92 lbid, 92-93.
} 
Sasa Djuarsa Sendiaja juga menyimpulkan bahwa teori komunikasi merupakan konseptualitas atau penjelasan logis tentang fenomena peristiwa komunikasi dalam kehidupan manusia. Peristiwa yang dimaksud oleh Berger dan Chaffee adalah produksi, proses, dan pengaruh dari sistem-sistem tanda dan lambang yang terjadi dalam kehidupan manusia. ${ }^{93}$

\section{Sifat Teori dalam Studi Komunikasi}

Teori memiliki sifat keilmiahan, karena sifat keilmiahannya teori bersifat lentur dan dinamis. Sifat lentur dan dinamis ini bahwa teori dapat mengalami penyesuaian apabila muncul data-data baru yang mengubah kesimpulan. ${ }^{94}$ Seperti juga waktu dan eksistensi. Komunikasi tidak komunikasi tidak mempunyai awal dan tidak mempunyai akhir, melainkan proses yang sinambung (continue). ${ }^{95}$

Pengetahuan ilmiah adalah ilmu pengetahuan atau singkatnya ilmu saja akumulasi pengetahuan yang telah disisteminasi dan diorganisasi sedemikian rupa; sehingga memenuhi asas pengaturan secara prosedural, metologis, teknis dan normatif akademis. Dengan demikian teruji kebenaran keilmiahannya sehingga memenuhi kesahehan atau validitas ilmu, atau secara ilmiah dapat dipertanggung jawabkan. Pengetahuan ilmiah dapat diperoleh secara sadar, aktif, sistematis, jenis

\footnotetext{
${ }^{93}$ Sasa Djuarsa Sendiaja, Memahami Teori Komunikasi: Pendekatan, Pengertian, Kerangka Analisis dan Perspektif, 12.

94 Hari Wahyono, Jurnal tentang Makna dan Fungsi Teori dalam Proses Berpikir Ilmiah dan dalam Proses Penelitian Bahasa, 206.

${ }^{95}$ Deddy Mulyana, Ilmu Komunikasi Suatu Pengantar, 120-121
} 
prosesnya secara prosedural, metodis dan teknis, tidak bersifat acak, dan diakhiri dengan verifikasi atau diuji kebenaran (validitas) ilmiahnya. ${ }^{96}$

Komunikasi sebagai proses dapat dianalogikan dengan pernyataan Heraclitus enam abad sebelum masehi bawah; "Seseorang tidak akan pernah melangkah di sungai yang sama dua kali". Komunikasi terjadi sekali waktu dan kemudian menjadi bagian dari sejarah kita. Dalam proses komunikasi, para peserta komunikasi saling mempengaruhi, seberapa kecilpun pengaruh itu, baik lewat komunikasi verbal ataupun lewat komunikasi nonverbal. Implikasi dari komunikasi sebagai proses yang dinamis dan transaksional adalah bahwa para peserta komunikasi berubah (dari sekedar berubah pengetahuan hingga berubah pandangan dunia dan prilakunya. ${ }^{97}$

Menurut Abraham Kaplan (1964), sifat teori bukan semata untuk menemukan fakta yang tersembunyi, tetapi suatu cara untuk melihat fakta, mengorganisasikan serta mereprentasikan fakta tersebut. Suatu teori harus sesuai dengan dunia ciptaan tuhan, dalam arti dunia yang sesuai dengan ciri yang dimilikinya sendiri. Dengan demikian, teori yang baik adalah teori yang sesuai dengan realitas kehidupan. Teori yang baik adalah teori yang konseptualisasi dan penjelasannya didukung oleh fakta serta dapat diterapkan dalam kehidupan nyata. ${ }^{98}$

Komunikasi bertujuan untuk mengubah sikap, mengubah opini atau pendapat/pandangan, mengubah prilaku, mengubah masyarakat. Karena itu pesan atau isi dari komunikasi tersebut harus benar-benar dapat dipercaya, sehingga tidak

\footnotetext{
${ }^{96}$ Aang Ridwan, Filsafat Komunikasi, 141-142.

97 Ibid, 122.

${ }^{98}$ Sasa Djuarsa Sendjaja, Memahami Teori Komunikasi: Pendekatan, Pengertian, Kerangka Analisis dan Perspektif, 13.
} 
menimbulkan keburukan kepada penerima. Paling tidak ada tiga yang dapat berpengaruh kepada penerima pesan;

a. Dampak kognitif adalah yang timbul pada komunikan yang menyebabkan dia menjadi tau dan meningkat intlektualitasnya

b. Dampak afektif adalah komunikator tidak hanya komunikan tahu, tetapi tergerak hatinya, menimbulkan perasaan tertentu, misalnya perasaan iba, terharu, sedih, gembira, marah, dan sebagainya

c. Dampak behavioral ialah dampak yang timbul pada komunikan dalam bentuk perilaku, tindakan atau kegiatan. ${ }^{99}$

\section{Ciri-Ciri Teori dalam Studi Komunikasi}

Teori memiliki tiga ciri-ciri umum yakni;

a. Semua teori adalah abstraksi mengenai suatu hal, dengan demikian teori sifatnya terbatas.

b. Semua teori adalah semua konstruksi pemikiran yang berisikan interpretasi mengenai suatu fenomena ciptaan individual manusia, oleh karena itu sifatnya relatif tergantung pada cara pandang si pencipta, sifat dan aspek hal lain yang diamati, serta kondisi-kondisi yang lain yang mengikat seperti waktu, tempat, dan lingkungan di sekitarnya.

c. Teori juga berisikan rekomendasi mengenai suatu tindakan yang dapat dilakukan. ${ }^{100}$

\footnotetext{
${ }^{99}$ Onong Uchjana Effendy, Dinamika Komunikasi, 7.
} 
Kemampuan berpikir yang ada pada diri manusia menyebabkan manusia mampu mengembangkan pengetahuan yang merupakan rahasia kekuasaan-Nya. Manusia mengembangkan pengetahuannya mengatasi kebutuhan kelangsungan hidupnya. Kemudian ia memikirkan hal-hal baru, menjelajah ufuk baru, karena hidup bukan hanya sekedar untuk kelangsungan hidupnya, melainkan lebih dari pada itu. ${ }^{101}$

Teori-teori baru akan selalu muncul apabila kemampuan berpikir manusia dapat digunakan dengan maksimal. Sebaliknya teori-teori akan minim atau terbatas jika kemampuan berpikir yang dimiliki manusia tidak dimanfaatkan dengan baik.

Dalam teori konstruksi sosial, diri merupakan ide atau prinsip utama dalam tradisi sosiokultural. Ide ini menyatakan bahwa dunia sosial kita tercipta karena adanya interaksi antara manusia. Cara kita berkomunikasi sepanjang waktu mewujudkan pengertian kita mengenai pengalaman, termasuk ide kita mengenai diri kita sebagai manusia dan sebagai komunikator. Dengan demikan pada dasarnya setiap orang memiliki teori masing-masing mengenai kehidupan. Teori itu menjadi model bagi manusia untuk memahami pengalaman hidupnya. ${ }^{102}$

Kemampuan yang dikembangkan manusia disebabkan oleh dua hal utama; a) Bahasa; manusia mempunyai bahasa yang mampu mengomunikasikan informasi dan jalan pikiran yang melatar belakangi informasi tersebut, b) kemampuan berpikir

${ }^{100}$ Sasa Djuarsa Sendjaja, Memahami Teori Komunikasi: Pendekatan, Pengertian, Kerangka Analisis dan Perspektif, 12.

101 Aang Ridwan, Filsafat Komunikasi, 123.

102 Morissan, Teori Komunikasi Individu Hingga Massa, 113-1 14. 
menurut satu alur kerangka berpikir. Secara garis besar, cara berpikir ini disebut penalaran. ${ }^{103}$

Menurut Harre, manusia adalah mahkluk yang terlihat atau diketahui secara publik serta memiliki sejumlah atribut dan sifat yang terbentuk di dalam kelompok budaya dan sosial. Menurut pandangan ini sifat manusia diatur oleh kebudayaan sedangkan sifat diri diatur teori yang dimiliki orang bersangkutan mengenai dirinya sendiri sebagai salah satu anggota suatu kebudayaan. Dengan demikian manusia sebagai mahkluk pribadi (personal being) memiliki dua sisi yaitu sisi sebagai mahkluk sosial dan sisi lainnya seagai makhluk pribadi. ${ }^{104}$

Komunikasi dilakukan dalam berbagai tingkat kesengajaan, dari tingkat komunikasi yang tidak disengaja sama sekali hingga komunikasi yang benar-benar direncanakan dan disadari. Kesengajaan bukanlah syarat untuk terjadinya komunikasi, meskipun kita sama sekali tidak bermaksud menyampaikan pesan kepada orang lain, prilaku kita potensial ditafsirkan orang lain. ${ }^{105}$

Makna pesan juga bergantung pada konteks fisik dan ruang (termasuk iklim, suhu, intensitas cahaya, dan sebaginya), waktu, sosial, psikologis. Waktu juga mempengaruhi makna terhadap suatu pesan. Kehadiran orang lain, sebagai konteks sosial juga akan mempengaruhi orang-orang yang berkomunikasi. ${ }^{106}$ Ciriciri teori dalam studi komunikasi tidak jauh dari konsep diri. Konsep diri adalah

\footnotetext{
103 Aang Ridwan, Filsafat Komunikasi, 123.

104 Morissan, Teori Komunikasi Individu Hingga Massa, 114.

105 Deddy Mulyana, Ilmu Komunikasi Suatu Pengantar, 111.

106 lbid, 113-114.
} 
pandangan kita mengenai siapa diri kita, dan itu hanya bisa kita peroleh lewat informasi yang diberikan orang lain kepada kita. ${ }^{107}$

Semakin maksimal celah atau kemampuan digunakan maka semakin baik pula komunikasi dan pesan-pesan yang disampaikan. Segala sesuatu tidak terlepas dari ruang dan waktu, fisik dan psikologis yang dialami oleh setiap orang, hendaknya manusia dalam berkomunikasi memberikan ruang gerak kepada dirinya untuk bisa menyesuaikan diri terhadap kapan, dimana, siapa dan bagaimana lawannya berkomunikasi.

\section{E. Peran dan Fungsi Teori dalam Studi Komuikasi}

Teori memiliki peran yang sangat penting, teori berperan membantu mendapatkan pengertian dan mengorganisasikan pengalaman. Di dalam teori terdapat posisi yang berperan penting dalam mengihtisarkan informasi sehingga penafsiran, penilaian, dan pernyataan dapat terlaksana dengan mudah. ${ }^{108}$

Teori adalah kebenaran yang tidak terbantahkan, sebelum muncul teori baru yang dapat membungkam teori tersebut. Keyakinan terhadap kebenaran teori ini menjadikan fungsi teori untuk menjelaskan kebenaran dalam menerangkan suatu gejala yang dapat dipertanggung jawabkan secara ilmiah, karena didukung oleh fakta-fakta empirik. Selain itu fungsi teori adalah memberikan penjelasan tentang gejala-gejala, baik bersifat alamiah maupun berisfat sosial. ${ }^{109}$

\footnotetext{
107 lbid, 8.

108 Hari Wahyono, Jurnal tentang Makna dan Fungsi Teori dalam Proses Berpikir Ilmiah dan dalam Proses Penelitian Bahasa, 205

109 Sunardi, Makalah Fungsi Teori dalam Konseling (PLB FIP UPI, 2008), 4.
} 
Berkaca melalui peran dan fungsi teori bahwa komunikasi memerlukan hal demikian. Mendapatkan pesan yang beragam sangat sulit untuk ditafsirkan oleh sebagaian orang. Cara pembedahan atau pembahasan secara rinci dan terarah sangat dibutuhkan oleh manusia sendiri. Dalam komunikasi ada yang disebut model.

Model adalah representasi suatu fenomena, baik nyata maupun abstrak, dengan menonjolkan unsur-unsur penting fenomena tersebut. Menurut Sereno dan Mortensen, model komunikasi merupakan diskripsi ideal mengenai apa yang dibutuhkan untuk terjadinya komunikasi. Sedangkan menurut B. Aubrey Fisher yang dikutip Sunardi, mengatakan model adalah analogi yang mengabstraksikan dan memilih bagian dari keseluruhan, unsur, sifat, atau komponen yang penting dari fenomena yang dijadikan model. ${ }^{110}$

Salah satu contoh dalam model tersebut adalah adalah verbal yakni model atau teori yang dinyatakan dengan kata-kata meskipun bentuknya sangat sederhana. Defenisi-defenisi komunikasi dirumuskan dalam kalimat-kalimat seperti model lasswell, Person dan Nelson, Tubbs dan Moss. Model verbal ini sering dibantu dengan grafik, diagram, atau gambar. ${ }^{111}$

Model komunikasi Lasswell "Who says what in which channel to whom wiht what effect". Artinya siapa mengatakan apa melalui saluran apa kepada siapa dengan dampak apa. Pandangan Laswell tentang komunikasi, seperti milik Aristoteles sekitar tahun 2000 tahun sebelumnya, menekankan unsur pembicaraan, pesan dan

\footnotetext{
${ }^{110}$ Deddy Mulyana, Ilmu Komunikasi Suatu Pengantar, 131-132.

${ }^{111}$ Ibid, 136.
} 
khalayak tetapi menggunakan istilah yang berbeda. Lasswell menawarkan defenisi yang lebih luas mengenai saluran yang memasukkan media masssa bersama-sama pidato sebagai bagian dari proses komunikasi. ${ }^{112}$

Menurut Littlejohn, fungsi teori ada 9 (sembilan), yakni;

a. Mengorganisasikan dan menyimpulkan pengetahuan tentang suatu hal. Ini berarti dalam mengamati realitas, kita tidak boleh melakukannya secara sepotong-sepotong. Kita perlu mengorganisasikan dan mensistensikan halhal yang terjadi dalam kehidupan dunia.

b. Memfokuskan artinya hal-hal atau aspek-aspek dari suatu objek yang diamati harus jelas fokusnya.

c. Menjelaskan maksudnya teori harus mampu membuat suatu penjelasan tentang hal yang diamatinya. Penjelasan ini tidak hanya berguna untuk menjelaskan pola-pola, hubungan-hubungan, tetapi juga untuk menginterpretasikan peristiwa-peristiwa tertentu.

d. Pengamatan menunjukkan bahwa teori tidak saja menjelaskan hal yang sebaiknya diamati, tetapi juga memberikan petunjuk cara mengamatinya.

e. Membuat prediksi, meskipun kejadian yang dialami berlaku pada masa lalu, namun berdasarkan data dan hasil pengamatan ini harus dibuat suatu perkiraan tentang keadaan yang bakal terjadi apabila hal-hal yang digambarkan oleh teori juga tercerminkan dalam kehidupan di masa sekarang. Fungsi prediksi ini terutama sangat penting bagi bidang-bidang komunikasi terapan, seperti persuasi dan perubahan sikap, komunikasi,

\footnotetext{
${ }^{112}$ Brent D. Ruben, Komunikasi dan Perilaku Manusia, 43.
} 
dalam organisasi, dinamika kelompok kecil, periklanan, public relaton, dan media massa.

f. Fungsi heuristic atau heurisme. Aksioma umum menyebutkan bahwa teori yang baik adalah teori yang mampu merangsang penelitian. Ini berarti bahwa teori yang diciptakan timbulnya upaya-upaya untuk melakukan penelitian selanjutnya.

g. Komunikasi menunjukkan bahwa teori seharusnya tidak menjadi monopoli si penciptanya. Teori harus dipublikasikan, didiskusikan, dan terbuka terhadap kritikan-kritikan.

h. Fungsi kontrol, bersifat normatif. Hal ini dikarenakan bahwa asumsi-asumsi teori dapat kemudian berkembang menjadi norma-norma atau nilai-nilai yang dipegang dalam kehidupan sehari-hari.

i. Fungsi generatif. Fungsi ini terutama sekali menonjol di kalangan pendukung tradisi/aliran pendekatan interpretatif dan teori kritis. Menurut pandangan ini, teori juga berfungsi sebagai sarana perubahan sosial dan kultural, serta sarana untuk menciptakan pola dan cara kehidupan yang baru. $^{113}$

Teori pada umumnya dibangun atas asumsi yang menggambarkan para pendirinya, tidak terkecuali teori pengurangan ketidakpastian yang memiliki sejumlah asumsi. Asumsi pertama mengatakan bahwa orang seringkali menghadapi

${ }^{113}$ Sasa Djuarsa Sendjaja, Memahami Teori Komunikasi: Pendekatan, Pengertian, Kerangka Analisis dan Perspektif, 12-14. 
ketidakpastian dalam hubungannya dengan orang lain. Asumsi kedua menyatakan ketidakpastian merupakan keadaan yang tidak disukai, dengan kata lain dibutuhkan energi yang cukup besar yang melibatkan emosi dan psikis untuk tetap berada dalam kondisi yang tidak pasti. Asumsi ketiga menyatakan jika orang bertemu dengan orang lain yang tidak dikenalnya maka muncul perhatian terhadap dua hal: menguranig ketidakpastian dan meningkatkan prediktabilitas. Asumsi keempat menyatakan komunikasi interpesonal merupakan proses yang melibatkan tahap perkembangan yang terdiri atas tiga tahap, yaitu sebagai masukan, personal dan keluaran. Asumsi kelima menyatakan komunikasi interpersonal adalah instrumen utama untuk mengurangi ketidakpastian. Asumsi keenam menyatakan memberikan tekanan kepada waktu, sekaligus fokus pada fakta bahwa komunikasi interpersonal berkembang secara bertahap. Dan asumsi terakhir menyatakan bahwa perilaku manusia dapat dapat diperkirakan sebaga aturan hukum alam, atau dengan kata lain prilaku manusia diatur oleh prinsip-prinsip yang berisfat umum atau universal sebagaimana atuaran hukum alam. ${ }^{114}$

Menurut Bargoon, ketika anda mulai berkomunikasi dengan orang lain, anda memiliki ide umum mengenai apa yang akan terjadi yang disebut Bargoon sebagai "posisi interaksi" (interaction position) yaitu tempat atau titik awal dimana anda akan memulai komunikasi. Posisi komunikasi ini ditentukan oleh kombinasi dari tiga faktor yang dinamakan RED yang merupakan singkatan dari requuire ments (kebutuhan), expectation (harapan), dan desires (keinginan). Kebutuhan adalah segala hal yang anda perlukan dalam interaksi, kebutuhan bersifat biologis seperti meminta makan,

\footnotetext{
${ }^{114}$ Morrissan, Psikologi Komunikasi (Bogor: Penerbit Ghalia Indonesia, 2010), 89-91.
} 
atau kebutuhan sosial, seperti kebutuhan untuk berafilisasi atau kebutuhan berteman. Harapan adalah pola-pola yang anda perkirakan akan terjadi. Jika anda tidak terlalu mengenal seseorang anda akan mengandalkan norma-norma kesopanan atau tujuan dari situasi tertentu seperti tujuan suatu pertemuan. Sedangkan keinginan anda adalah apa yang ingin anda capai, apa yang anda harapakan akan terjadi. ${ }^{115}$

\section{F. Penutup}

Komunikasi berlandaskan teori sangat penting, untuk mengungkap asumsiasumsi dan karekteristik seseorang, simbol dan lainnya tidak bisa mengandalkan satu persepsi saja, melainkan harus menimbulkan katagori-katagori dalam bidang tertentu yang ditentukan ruang, waktu dan jenis keilmuan-keilmuan komunikasi yang beragam, diantaranya adalah teori komunikasi, teori komunikasi politik, teori komunikasi interpersonal, teori komunikasi intrapersonal, teori komunikasi budaya, teori komunikasi massa, dan teori komunikasi-komunikasi lainnya.

Penyatuan antra teori dan komunikasi haruslah secara terperinci, karena dalam komunikasi tidak pernah terlepas dari gejala-gejala, fenomena-fenomena, intraksi dan lainnya yang membutuhkan penafsiran. Dengan demikian hadirnya teori dalam ranah studi komunikasi memberikan warna baru dan keilmuan yang lebih luas terhadap ilmu komunikasi itu sendiri.

Komunikasi adalah sebuah proses, yakni dalam melakukan suatu kegiatan yang memiliki banyak langkah terpisah tetapi saling berhubungan. Komunikasi tidak

\footnotetext{
115 Morissan, Teori Komunikasi Individu Hingga Massa, 213-214.
} 
Tasâmuh Volume 16, No. 1, Desember 2018

terlepas dari sebuah simbol, manusia adalah salah satu hewan yang menggunakan lambang, dan itulah yang membedakan antara manusia dengan makluk lainnya. 


\section{Daftar Pustaka}

Akbar, Putra, Kamus Ilmiah Populer: Refrensi Ilmiah, Sains, Politik, Hukum, Sosial, dan Budaya Juga dilengkapi dengan Pengetahuan Ilmiah dan Umum. Penerbit Wipress, 2009.

D. Rubent, Breent, Komunikasi dan Perilaku Manusia. Jakarta: PT RajaGrafindo Persada, 2013.

Effendy, Onong Uchjana, Dinamika Komunikasi. Bandung: PT Remaja Rosdakarya, 2008.

Harun, Rochajat \& Ardianto, Elvinaro, Komunikasi Pembangunan Perubahan Sosial: Perspektif Dominan, Kaji Ulang, dan Teori Kritis. Jakarta: PT RajaGrafindo Persada, 2011.

Morisson, Teori Komunikasi Individu Hingga Massa. Jakarta: Kharisma Putra Utama, 2014.

-----Psikologi Komunikasi. Bogor: Penerbit Ghalia Indonesia, 2010.

Muhtadi, Saeful, Filsafat Komunikasi. Bandung: CV Pustaka Setia, 2013.

Mulyana, Deddy, Ilmu Komunikasi Suatu Pengantar. Bandung: PT Remaja Rosdakarya, 2013.

Ridwan Aang, Filsafat Komunikasi. Bandung: CV Pustaka Setia, 2013.

Sendjaja, Sasa Diuarsa, Memahami Teori Komunikasi: Pendekatan, Pengertian, Kerangka Analisis dan Perspektif. Univeritas Tebruka: Modul Kegiatan Pembelajaran, 2014.

Sugiyono, Metode Penelitian Kuantitatif Kualitatif dan R\&D. Bandung: CV Alfabeta, 2013.

Sunardi, Makalah Fungsi Teori dalam Konseling. PLB FIP UPI, 2008. 
Tasâmuh Volume 16, No. 1, Desember 2018

Wahyono, Hari, Jurnal tentang Makna dan Fungsi Teori dalam Proses Berpikir Ilmiah dan dalam Proses Penelitian Bahasa. Magelang: FKIP Universitas Magelang, 2005. 


\section{Petunjuk Penulisan}

Tasâmuh menerima tulisan dalam bentuk artikel dan laporan penelitian, baik yang menggunakan bahasa Indonesia, Inggris, maupun Arab, dengan ketentuan sebagai berikut:

1. Tulisan tersebut belum pernah diterbitkan atau dipublikasikan dalam suatu jurnal berkala atau buku.

2. Topik tulisan berkisar pada kajian-kajian yang berkaitan dengan ilmu dakwah dan Komunikasi.

3. Judul tulisan maksimal 14 kata.

4. Semua tulisan harus menyertakan abstrak (100-150 kata) dan kata kunci (3-7 kata).

5. Jumlah halaman antara 15-20 nomor halaman dengan ukuran kwarto spasi ganda dengan menggunakan jenis huruf Futura $\mathrm{Lt} \mathrm{B} \dagger$ dan besar hurup 12 pt.

6. Setiap kata Arab yang belum resmi terbakukan dalam bahasa Indonesia ditulis mengikuti pedoman transliterasi yang ditetapkan dan cara penulisannya dimiringkan (italic), hal ini juga berlaku untuk kata-kata asing yang lain (seperti bahasa Inggris dan bahasa Daerah) dan cara penulisannya dimiringkan (italic),

7. Transliterasi tidak berlaku untuk nama orang, tempat, institusi, dan sejenisnya.

8. Penulis menyerahkan file beserta print out naskahnya.

9. Semua tulisan menggunakan referensi model footnote dengan teknik penulisan sebagai berikut: Nama Penulis, Judul Buku Yang Ditulis Miring (Kota Penerbit: Nama Penerbit, Tahun Terbit), Nomor Halaman. Sebagai contoh:

a. Buku atau Kitab:

- John Lewis Coser, The Function of Social Conflict (New York: Free Press, 1969), 125. 
- Sofian Effendi, Membangun Martabat Manusia Dalam Perspektif Islam (Yogakarta: UGM Press, 2005), 24.

- Ibnu Jarir al-Thabari, Jami' al-Bayan, Jilid 9 (Beirut: Dar alKutub Ilmiyah, 1992), 67.

b. Buku Terjemahan:

David Hill, Pengembangan dan Pemberdayaan Masyarakat, ter. Adam Hulaimi, Jilid 2 (Jakarta: Pustaka Pelajar, 1997), 127.

c. Artikel dalam Buku atau Ensiklopedi:

- Nurcholis Majid, "Cendekiawan dan Penguatan Civil Society di Indonesia" dalam Peran Cendekiawan Muslim Dalam Menegakkan Hak Politik Civil Society, ed. Tim Editor Masika (Jogjakarta: Bintang Budaya, 1996), 124.

- D.S. Adam, "Theology," Encyclopedia of Religion and Ethics, ed. James Hastings, Jilid 4 (New York: Charles Scribner's Sons, tt), 293.

d. Artikel dalam Jurnal:

Faisal Ismail, "On Developing Liberation Theology in Islam," dalam Jurnal Gazwatul Fikri, Vol. 9 No. 2 (Yogyakarta: Fakultas Dakwah UIN Sunan Kalijaga, Desember 1999), 165.

e. Artikel dalam Media Massa:

Fawaizul Umam, "Quo Vadis Kebebasan Beragama di Indonesia", dalam Koran KOMPAS, Edisi 30 Maret 2001, 4.

f. Kitab Suci:

QS. al-Qashash (28): 5. Perjanjian Baru, Yoh ( 20): 31.

g. Bila mengutip ulang referensi yang sama secara berurut, maka cukup tulis: Ibid. Jika halamannya berbeda, cukup tambahkan nomor halamannya: Ibid., 14.

h. Bila referensi terkutip ulang berselang oleh satu atau lebih referensi berbeda, maka cukup tulis last name pengarang berikut satu kata awal judul dari referensi dimaksud. Misalnya, Zahrah, Ushûl..., 35. 
10. Selain mencantumkan footnote, penulis juga harus mencantumkan DAFTAR PUSTAKA dengan aturan penulisan diurutkan secara alfabetis. Nama penulis diketik dengan mendahulukan nama marga atau nama akhir jika nama penulis terdiri dari 2 kata atau lebih, judul buku atau nama jurnal maupun nama media massa ditulis miring (Kota Penerbit: Lembaga Penerbit, Tahun Terbit) tanpa diakhiri tanda titik.

Contoh:

a. Buku: Nasution, Harun, Perkembangan Pemikiran Cendikiawan Muslim Indonesia (Jakarta: Dunia Ilmu, 1998)

b. Jurnal: Ismail, Faisal, "On Developing Liberation Theology in Islam," dalam Jurnal Gazwatul Fikri, Vol. 9 No.2 (Yogyakarta: Fakultas Dakwah UIN Sunan Kalijaga, Desember 1999)

c. Media massa: Umam, Fawaizul, "Quo Vadis Kebebasan Beragama di Indonesia", dalam Koran KOMPAS, Edisi 30 Maret 2001

d. Makalah: Akbar, Muhammad, "Membangun Paradigma Baru Fakultas Dakwah", dalam Makalah Seminar Pengembangan Fakultas Dakwah di Indonesia, Mataram, 3 Maret 2004 